\title{
Implementasi Pengelolaan Pariwisata Berkelanjutan Di Kota Semarang
}

\section{Implementation of Sustainable Tourism Management in Semarang City}

\author{
Siauw Tiffani Setiono, Teuku Afrizal, Eko Supriyono, Rinaldy May Wendra \& \\ Annisa Nurfitriani
}

Magister Administrasi Publik Fakultas Ilmu Sosial dan Ilmu Politik, Universitas Diponegoro, Indonesia

Diterima: 25 Juni 2020; Disetujui: 13 Desember 2020; Dipublish: 31 Januari 2021

\begin{abstract}
Abstrak
Pariwisata merupakan salah satu bidang yang dapat meningkatkan pendapatan asli daerah. Kota Semarang, memiliki ikon kota lama yang dapat menjadi daya tarik kuat bagi aspek pariwisata. Penelitian bertujuan untuk mengetahui rencana dan program pengembangan pariwisata, keterlibatan organisasi dan pihak-pihak terkait lainnya, mekanisme pelaksanaan pengembangan pariwisata, serta pola pengawasan yang dilakukan guna pengembangan pariwisata yang berkelanjutan. Pola pengembangan pariwisata berkelanjutan ini memiliki harapan besar pada tetap terjaganya lingkungan hidup. Dalam pelaksanaannya mereplikasi model Pentahelix, dimana melibatkan komponen Pemerintah, Swasta, Komunitas, Akademisi serta Media massa. Dengan demikian pengelolaan pariwisata di Kota Semarang menjadi tanggung jawab semua stakeholders. Sehingga tujuan pariwisata yang dapat menunjang pendapatan daerah maupun pusat tanpa mengesampingkan lingkungan hidup. Rekomendasi yang dapat diusulkan yaitu Pengoptimalan potnesi wisata alam dan budaya sebagai ikon wisata daerah; Pembangunan pariwisata berkelanjutan perlu dilakukan dengan memberdayakan masyarakat lokal.

Kata Kunci : Parawisata Berkelanjutan, Optimalisasi Potensi Wisata, Kerjasama Stakeholders
\end{abstract}

\begin{abstract}
Tourism is one of the fields that can increase local revenue. Semarang City, has an old city icon that can be a strong attraction for the tourism aspect. The research aims to determine tourism development plans and programs, the involvement of organizations and other relevant parties, the mechanism of implementing tourism development, and the pattern of supervision carried out for sustainable tourism development. This pattern of sustainable tourism development has high hopes for the preservation of the environment. In its implementation, it replicates the Pentahelix model, which involves Government, Private, Community, Academic and mass media components. Thus the management of tourism in the city of Semarang is the responsibility of all stakeholders. So that tourism destinations that can support regional and central income without ignoring the environment. Recommendations that can be proposed are Optimizing the potential of natural and cultural tourism as regional tourism icons; Sustainable tourism development needs to be done by empowering local communities.

Keywords: Sustainable Tourism, Optimization of Tourism Potential, Cooperation of Stakeholders
\end{abstract}

How to Cite: Setiono, T.S., Afrizal, T., Supriyono, E., Wendra, M.W., \& Nurfitriani, A. (2021). Implementasi Pengelolaan Pariwisata Berkelanjutan Di Kota Semarang.PERSPEKTIF, 10(1): 26-35

*Corresponding author:

E-mail: Siauw12@gmail.com

ISSN 2085-0328 (Print)

ISSN 2684-9305(Online) 


\section{PENDAHULUAN}

Rencana Strategis Pariwisata Berkelanjutan dan Pekerjaan Layak yang Ramah Lingkungan di Indonesia bertujuan mengajak-serta berbagai mitra nasional dalam bertukar pandangan dan membangun konsensus untuk membangun industri kepariwisataan yang kuat di Indonesia yang menciptakan Pekerjaan Layak yang Ramah Lingkungan. Penyiapan Rencana Strategis dimaksudkan untuk membantu Pemerintah, berbagai mitra sosial dan masyarakat luas umumnya untuk mengenal penting dan strategisnya kepariwisataan berkelanjutan dalam pembangunan Indonesia dan menemukenali langkah langkah menuju ke arah itu melalui serangkaian strategi kunci yang dapat didukung pada tingkat nasional, provinsi dan lokal. Rencana Strategis ini dirancang berdasarkan pada proses konsultasi yang melibatkan berbagai kelompok pemangku kepentingan kunci dari semua tingkat pemerintahan, berbagai komunitas, industri, lembaga pendidikan dan pelatihan, mitra sosial dan masyarakat umum, mengidentifikasi "ramuan"/unsurunsur yang hilang untuk dapat memperoleh kemauan politis yang sudah nyata melembaga kuat dalam pembangunan

berkelanjutan.

Pariwisata dan ekonomi kreatif memainkan peran penting dalam pembangunan Indonesia. Hal ini dapat dilihat antara lain dari kontribusinya terhadap PDB dan lapangan kerja, baik langsung maupun tidak langsung. Secara bersamaan, pariwisata dan ekonomi kreatif memberikan kontribusi 11,8\% terhadap PDB Indonesia dan 14,66\% terhadap total lapangan kerja. Dalam mengembangkan sektor ini, Kementerian Pariwisata dan Ekonomi Kreatif telah menetapkan visi yaitu "terwujudnya kesejahteraan dan kualitas hidup rakyat Indonesia, melalui pariwisata dan ekonomi kreatif". Keberlanjutan jelas merupakan kunci dalam pencapaian visi ini, karena kualitas hidup tidak akan pernah menjadi kenyataan tanpa keberlanjutan. (laporan Kemenparekraf, 2012). Hal ini menunjukkan bahwa sektor pariwisata menjadi salah saru komoditi pengembangan yang menjadi prioritas pembangunan nasional. Hal ini juga didasari dalam Undang-Undang Kepariwisataan No. 10 Tahun 2009 tentang kepariwisataan.

Sebagai tindak lanjut terhadap Undang-Undang Kepariwisataan No. 10 Tahun 2009, dan dalam rangka pelaksanaan kegiatan kepariwisataan dan untuk meningkatkan daya saing Kota Semarang yang dilandasi nilai-nilai budaya bangsa dan kearifan lokal masyarakat yang dilakukan secara sistematis, terencana, terpadu,berkelanjutan, dan bertanggung jawab. Maka Pemerintah Kota Semarang membuat Perda tentang Kepariwisataan Nomor 3 Tahun 2010. Perda ini sebagai dasar Regulasi dari Pemerintah Kota Semarang dalam melaksanakan kebijakan tentang Kepariwisataan.

Kota Semarang memiliki kawasan yang pada abad 18 menjadi pusat perdagangan dan kini disebut Kawasan Kota Lama atau disebut Outstadt dengan luas sekitar 31 ha dan mendapat julukan "Little Netherland". Di daerah ini ada sekitar 50 bangunan kuno dan mempunyai sejarah kolonial. Kota Lama adalah daerah yang dinilai berpotensi dikembangkan untuk bidang kebudayaan ekonomi wilayah konservasi (http://www.semarang.go.id).

Apabila dicermati dengan seksama, pembangunan kepariwisataan di kawasan ini akan menimbulkan dampak-dampak negatif, khususnya terhadap kondisi fisik bangunan-bangunannya yang tua dan rentan terhadap perubahanperubahan fisik. Permasalahan dan kendala dalam pengembangan adalah sebagai berikut: 1) Hampir matinya Spirit of Place kawasan (ibarat raga yang sudah mau ditinggalkan jiwanya); 2) Kepemilikkan bangunan yang 
sering berpindah-pindah (status quo); 3) Tingkat partisipasi stakeholder masih kurang; 4) Kemampuan pemerintah terbatas (terutama finansial); 5) Kawasan yang terletak pada daerah rawan banjir/rob dan land subsidence.

Dengan kondisi demikian, maka diperlukan konsep kajian pengembangan pariwisata berkelanjutan. Agar pariwisata yang dikembangkan tidak menambah buruk kondisi alam di masa yang akan datang.

\section{METODE PENELITIAN}

Jenis penelitian ini adalah penelitian dengan pendekatan kualitatif, di mana penelitian kualitatif adalah penelitian dengan filsafat postpovitisme digunakan pada kondisi objek yang alamiah dan peneliti sebagai informan kunci, teknik pengumpulan data dengan triangulasi dan analisis data bersifat kualitatif sehingga hasil penelitian kualitatif lebih menekankan makna dari pada hanya sebuah generalisasi sehingga proses dan makna selalu ditonjolkan dalam proses penelitian kualitatif (Sugiyono, 2015). Jenis dan sumber data dari penelitian ini digolongkan dalam dua kategori, yaitu data primer di mana data tersebut merupakan data yang diperoleh langsung dan dikumpulkan melalui observasi, kemudian data sekunder merupakan data yang diperoleh dari sumber bacaan dan sumber-sumber lainya bisa dari surat pribadi, buku harian dan dokumendokumen resmi dari instansi pemerintah (Moleong, 2012).

Metode pengumpulan data yang dilakukan adalah observasi langsung serta studi literasi terkait pengelolaan kepariwisataan berkelanjutan di Kota Semarang. Analisis data yang peneliti lakukan memakai model interaktif (Miles, Huberman, dan Saldana, 2014) di mana kegiatan analisis data terdiri dari kegiatan reduksi data, penyajian data, serta penarikan kesimpulan.

\section{HASIL DAN PEMBAHASAN \\ Pengembangan \\ Pariwisata \\ Berkelanjutan di Kota Semarang}

Pariwisata Berkelanjutan atau

Sustainable Tourism adalah pariwista yang berkembang sangat pesat, termasuk pertambahan arus kapasitas akomodasi, populasi lokal dan lingkungan, dimana perkembangan pariwisata dan investasi investasi baru dalam sektor pariwisata seharusnya tidak membawa dampak buruk dan dapat menyatu dengan lingkungan, jika kita memaksimalkan dampak yang positif dan meminimalkan dampak negative. Maka beberapa inisiatif diambil oleh sektor public untuk mengatur pertumbuhan pariwisata agar menjadi lebih baik dan menempatkan masalah akan sustainable tourism sebagai prioritas karena usaha atau bisnis yang baik dapat melindungi sumber - sumber atau asset yang penting bagi pariwisata tidak hanya untuk sekarang tetapi dimasa depan.

Adapun

prinsip-prinsip pengembangan pariwisata berkelanjutan meliputi

Partisipasi. Masyarakat setempat harus mengawasi atau mengontrol pembangunan pariwisata dengan ikut terlibat dalam menentukan visi pariwisata, mengidentifikasi sumber- sumber daya yang akan dipelihara dan ditingkatkan, serta mengembangkan tujuan- tujuan dan strategi-strategi untuk pengembangan dan pengelolaan daya tarik wisata. Masyarakat juga harus berpartisipasi dalam mengimplementasikan strategi-strategi yang telah disusun sebelumnya. Partisipasi masyarakat dalam pengembangan pariwisata didukung dengan program Kelompok Sadar Wisata (Pokdarwis). Program ini sebagai bentuk stimulan Pemerintah Kota Semarang dalam pengembangan pariwisata dengan melibatkan masyarakat secara langsung. Program ini dijalankan pada tingkat kelurahan dengan mengoptimalkan potensi yang dimiliki. Sebagai contoh 
Pokdarwis Nongkosawit di daerah Gunungpati Semarang.

Keikutsertaan

Para

Pelaku/Stakeholder Involvement. Para pelaku yang ikut serta dalam pembangunan pariwisata meliputi kelompok dan institusi LSM (Lembaga Swadaya Masyarakat), kelompok sukarelawan, pemerintah daerah, asosiasi wisata, asosiasi bisnis dan pihak-pihak lain yang berpengaruh dan berkepentingan serta yang akan menerima dampak dari kegiatan pariwisata. Peran pelaku lain dalam pengembangan pariwisata Kota Semarang melibatkan bisnis agen wisata Association of The Indonesian Tours And Travel Agencies (ASITA) atau Asosiasi Perusahaan Perjalanan Wisata Indonesia. Asosiasi bisnis lainnya yaitu Perhimpunan Hotel dan Restoran Indonesia (PHRI).

Kepemilikan Lokal. Pembangunan pariwisata harus menawarkan lapangan pekerjaan yang berkualitas untuk masyarakat setempat. Fasilitas penunjang kepariwisataan seperti hotel, restoran, dsb. seharusnya dapat dikembangkan dan dipelihara oleh masyarakat setempat. Beberapa pengalaman menunjukkan bahwa pendidikan dan pelatihan bagi penduduk setempat serta kemudahan akses untuk para pelaku bisnis/wirausahawan setempat benarbenar dibutuhkan dalam mewujudkan kepemilikan lokal. Lebih lanjut, keterkaitan (linkages) antara pelakupelaku bisnis dengan masyarakat lokal harus diupayakan dalam menunjang kepemilikan lokal tersebut. Pelaku bisnis sebagai bentuk kepemilikan lokal meliputi bisnis oleh-oleh. Di Kota Semarang, pusat oleh-oleh ini berada di sekitar jalan Pandanaran. Kelompok pengusaha lokal ini tergabung dalam Asosiasi Pedagang Pandanaran Semarang (APPS).

Penggunaan Sumber Daya yang Berkelanjutan. Pembangunan pariwisata harus dapat menggunakan sumber daya dengan berkelanjutan yang artinya kegiatan-kegiatannya harus menghindari penggunaan sumber daya yang tidak dapat diperbaharui (irreversible) secara berlebihan. Hal ini juga didukung dengan keterkaitan lokal dalam tahap perencanaan, pembangunan dan pelaksanaan sehingga pembagian keuntungan yang adil dapat diwujudkan. Dalam pelaksanaannya, kegiatan pariwisata harus menjamin bahwa sumber daya alam dan buatan dapat dipelihara dan diperbaiki dengan menggunakan kriteriakriteria dan standar-standar internasional.

\section{Mewadahi}

Tujuan-tujuan

Masyarakat. Tujuan-tujuan masyarakat hendaknya dapat diwadahi dalam kegiatan pariwisata agar kondisi yang harmonis antara pengunjung/wisatawan, tempat dan masyarakat setempat dapat terwujud. Misalnya, kerja sama dalam wisata budaya atau cultural tourism partnership dapat dilakukan mulai dari tahap perencanaan, manajemen, sampai pada pemasaran.

Daya Dukung. Daya dukung atau kapasitas lahan yang harus dipertimbangkan meliputi daya dukung fisik, alami, sosial dan budaya. Pembangunan dan pengembangan harus sesuai dan serasi dengan batas-batas lokal dan lingkungan. Rencana dan pengoperasiannya seharusnya dievaluasi secara reguler sehingga dapat ditentukan penyesuaian/perbaikan yang dibutuhkan. Skala dan tipe fasilitas wisata harus mencerminkan batas penggunaan yang dapat ditoleransi (limits of acceptable use). Daya dukung pengembangan pariwisata ini juga melibatkan Akademisi, Media massa, Sawsta serta komunitas. Atau dalam istilah Pentahelix.

Monitor dan Evaluasi. Kegiatan monitor dan evaluasi pembangunan pariwisata berkelanjutan mencakup penyusunan pedoman, evaluasi dampak kegiatan wisata serta pengembangan indikator-indikator dan batasan-batasan untuk mengukur dampak pariwisata. Pedoman atau alat-alat bantu yang dikembangkan tersebut harus meliputi skala nasional, regional dan lokal. Dalam 
pengembangan pariwisata berkelanjutan di Kota Semarang, aspek monitor dan evaluasinya menjadi ranah dari peran DPRD Kota Semarang. Lembaga ini berperan dalam pengawasan kinerja Pemerintah dalam pengembangan pariwisata sesuai dengan konspe-konsep yang direncanakan.

Akuntabilitas.

Perencanaan pariwisata harus memberi perhatian yang besar pada kesempatan mendapatkan pekerjaan, pendapatan dan perbaikan kesehatan masyarakat lokal yang tercermin dalam kebijakan-kebijakan pembangunan. Pengelolaan dan pemanfaatan sumber daya alam seperti tanah, air, dan udara harus menjamin akuntabilitas serta memastikan bahwa sumber-sumber yang ada tidak dieksploitasi secara berlebihan.

Pelatihan. Pembangunan pariwisata berkelanjutan membutuhkan pelaksanaan program- program pendidikan dan pelatihan untuk membekali pengetahuan masyarakat dan meningkatkan keterampilan bisnis, vocational dan profesional. Pelatihan sebaiknya meliputi topik tentang pariwisata berkelanjutan, manajemen perhotelan, serta topik- topik lain yang relevan.

Promosi. Pembangunan pariwisata berkelanjutan juga meliputi promosi penggunaan lahan dan kegiatan yang memperkuat karakter lansekap, sense of place, dan identitas masyarakat setempat. Kegiatan-kegiatan dan penggunaan lahan tersebut. Promosi pariwisata di Kota Semarang secara formal menjadi peran dari Badan Promosi Pariwisata Kota Semarang (BP2KS). Sesuai dengan Perwal Kota Semarang Nomor 2 Tahun 2012, peran BP2KS meliputi; Untuk lebih jelasnya dapat dilihat poin-poin di bawah ini : a. Tugas pertama yaitu meningkatan citra kepariwisataan Kota Semarang, b. Tugas kedua yaitu meningkatan kunjungan wisatawan mancanegara dan penerimaan sektor pariwisata, c. Tugas ketiga yaitu meningkatkan kunjungan wisatawan nusantara dan pembelanjaan, d. Melaksanakan tugas menggalang pendanaan dari sumber selain APBD Kota Semarang, e. Melaksanakan tugas riset pengembangan usaha dan bisnis pariwisata

\section{Pelaksanaan Pengembangan Pariwisata Berkelanjutan Mancanegara}

Karena pengembangan pariwisata di daerah tertentu sangat tergantung pada daya tarik alam dan antropogenik yang terletak di sekitarnya, praktik pembangunan berkelanjutan menjadi semakin penting. Jika sumber daya ini dihancurkan atau diturunkan, daya tarik destinasi berkurang juga, tetapi juga menimbulkan pertanyaan untuk pengembangan pariwisata di wilayah ini, karena calon wisatawan tertarik untuk berkunjung tujuan menarik dan bersih yang menawarkan layanan dengan kualitas tinggi. Namun, lingkungan yang tidak memiliki atribut lingkungan yang berkualitas tidak hanya tidak menarik bagi wisatawan, tetapi di lingkungan itu juga tidak terasa nyaman dan populasi domestik.

Kementerian Pariwisata berupaya memasukkan Kota Semarang sebagai salah satu dari 10 kota di Indonesia menjadi daerah tujuan Meeting, Incentives, Convention, Exhibitions (MICE). Semarang menempati peringkat ke 9 MICE di Indonesia dan merupakan salah satu dari 16 destinasi kota MICE unggulan di Indonesia. Ditinjau dari segi fasilitas Kota Semarang memiliki potensi yang baik untuk menjadikan Semarang sebagai Kota MICE, selain dari segi fasilitas Semarang sebagai Kota MICE didukung pula dengan adanya daya tarik wisata yang dimiliki sehingga akan semakin menarik wisatawan untuk berkunjung. 
Tabel 1.

Potensi Daya Tarik Kota Semarang

\begin{tabular}{lll}
\hline No. & Jenis Wisata & Jumlah \\
\hline 1. & Wisata Alam & 10 \\
\hline 2. & Wisata Buatan & 29 \\
\hline 3. & Wisata Budaya & 32 \\
\hline & Sumber: Dinas Kebudayaan dan Pariwisata Kota Semarang
\end{tabular}

Berdasarkan tabel 1, setidaknya kota Semarang memiliki potensi daya tarik wisata yang cukup banyak. Perencanaan pengembangan pariwisata berkelanjutan sebenarnya menyangkut perencanaan pelestarian lingkungan. Meliputi berbagai penelitian dan analisis sebelum membuat keputusan tentang penentuan arah pengembangan. Konsep pembangunan berkelanjutan didasarkan pada empat prinsip dasar, yaitu: 1) Prinsip kelestarian lingkungan, yang menyediakan pembangunan agar kompatibel dengan pemeliharaan proses ekologis penting, keanekaragaman hayati dan sumber daya hayati; 2) Prinsip keberlanjutan sosial, menyediakan pembangunan agar kompatibel dengan nilai-nilai tradisional komunitas, sambil menambahkan penguatan identitas mereka; 3) Prinsip keberlanjutan, memberikan pengembangan budaya agar kompatibel dengan budaya nilai-nilai komunitas manusia, yang juga berdampak pada penguatan identitas mereka; 4) Prinsip pembangunan ekonomi berkelanjutan untuk menyediakan sumber daya dan biaya yang efektif dikelola dengan cara yang dapat mereka gunakan dan generasi mendatang.

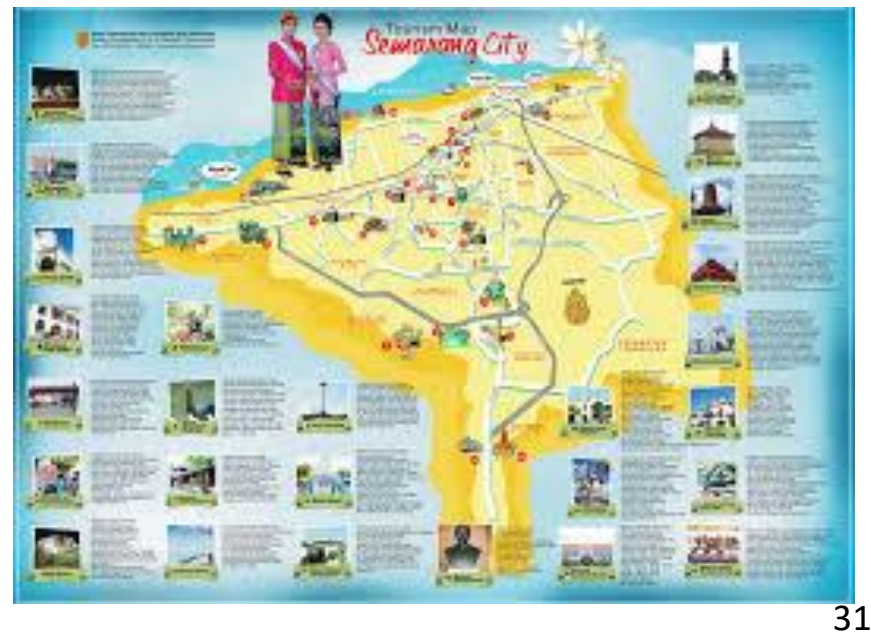

Gambar 1. Peta wisata Kota Semarang

Berdasarkan Perda Kota Semarang No 5 Tahun 2015 tentang Rencana Induk Pembangunan Pariwisata Kota Semarang, telah dikelompokkan perwilayahan pembangunan destinasi pariwisata Kota, sesuai Pasal 12.

a. Satu Destinasi Pariwisata Kota (DPK) mencakup seluruh wilayah Kota

b. Tiga Kawasan Strategis Pariwisata Kota (KSPK), yaitu: KSPK Semarang Tengah dan sekitarnya; Yang dimaksud "KSPK Semarang Tengah dan sekitarnya" meliputi wilayah Pusat Kota Semarang dan sekitarnya, Kawasan tersebut memiliki berbagai jenis Daya Tarik Wisata (DTW), yaitu:

a) Wisata Budaya:
1) Kawasan Masjid Agung Semarang, Kauman dan Kawasan Pasar Johar;
2) Stasiun Kereta Api Tawang, Gereja Blenduk, Gereja Gedangan dan Kawasan Kota Lama

3) Klenteng Tay Kak Sie, Kawasan Pecinan, Pekojan, Petudungan, dan Kampung Bustaman;

4) Kawasan Kampung Kulitan;

5) Kawasan Kampung Batik;

6) Kawasan Kampung Melayu, Masjid Menara Jl Layur;

7) Masjid Sekayu;

8) Kawasan Seni dan Budaya Sobokarti;

9) Kawasan Tugu Muda, Lawang Sewu, Museum Mandala 
Bhakti, Wisma Perdamaian, Gereja Katedral;

10)Kawasan Sam Poo Kong, Kawasan Tugu Soeharto;

11)Tugu Ketenangan Jiwa;

12)Kawasan Taman Budaya Raden Saleh (TBRS);

13)Puri Maerokoco;

14)Museum Ronggowarsito;

15)Makam Ki Ageng Pandanaran dan Kyai Sholeh Darat;

16)Masjid Agung Jawa Tengah;

17)Masjid Baiturrahman

b) Wisata Alam

1) Pantai Maron, Kawasan Pantai Marina, Sungai Banjir Kanal Barat

2) Kawasan Tanjung Emas, Kawasan Tambak Lorok

3) Wisata Buatan

4) Waterboom Bukit Wahid/Junggle Toon;

5) Wisata Anjungan Bandar Udara Ahmad Yani;

6) Kawasan Pusat Rekreasi dan Promosi Pembangunan (PRPP), Kawasan Kampung Laut;

7) Kolam Renang Paradise Club;

8) Pusat oleh-oleh dan kuliner jalan Pandanaran dan Pusat Kuliner Pekunden;

9) Duta Pertiwi Mall (DP Mall), Paragon City Mall, dan PlaPlay Indoor Theme Park Setos;

10)Citraland Mall, Matahari Plaza Simpang Lima, Kawasan Simpang Lima, dan Gajah Mada Plaza;

11)Merbie Centre;

12)Internasional Sport Club, Oasis Swimming Pool, dan Java Super Mall,

13)Pasar Burung Karimata,

14)Kolam Renang Jatidiri,

15)Water Blaster Perumahan Graha Candi Golf

16)Lotte Mart

2. KSPK Tugu-Ngalian dan sekitarnya
Yang dimaksud "KSPK TuguNgaliyan dan sekitarnya"meliputi Krapyak, Tugu, Mangkang dan Ngaliyan. Kawasan tersebut memiliki berbagai jenis DTW, yaitu:

a). Wisata Budaya:

1). Kawasan Tugu Batas Kerajaan Majapahit dengan Kerajaan Pajajaran;

2). Sedekah laut di Mangunharjo

b). Wisata Alam

1). Ekowisata Manggrove dan Wisata Bahari Tugurejo

c). Wisata Buatan

1). Taman Margasatwa Semarang dan Taman Lalu Lintas,

2). Kampung Wisata Taman Lele;

3). Kolam Renang Tirta Indah;

4). Rumah makan dan Pemancingan Lembah Kalipancur;

5). Omah Herboris.

3. KSPK Mijen - Gunungpati dan sekitarnya

Yang dimaksud "KSPK MijenGunungpati dan sekitarnya" meliputi wilayah Mijen, Gunungpati dan sekitarnya, Kawasan tersebut memiliki berbagai jenis DTW, yaitu:

a). Wisata Budaya:

1). Desa Wisata Wonolopo Mijen, Makam Raden Sumantri, Rumah Joglo Paweningjati Wonolopo;

2). Desa Wisata Kandri dan Desa Wisata Nongkosawit Gunungpati ;

3). Makam Joyo Kusumo dan Makam Pragolapati Gunungpati. 
4). Petilasan Jati Ombo BSB.

b). Wisata Alam:

1). Kebun UPTD Balai Benih dan Pembibitan Anggrek Dinas Pertanian;

2). Agrowisata Kebun Durian $\mathrm{H}$. Djauhari Mijen, dan Kebun Buah Eyang Sri;

3). Kebun Karet Karyadeka Lestari, Gua Kreo Gunungpati, Wisata Tubing Kali kranji,Tubing kali kripik, dan Tubing Kali Kreo;

4). Agrowisata Sikumbang di Gunungpati,

5). Agrowisata Cepoko di Gunungpati,

6). Agrowisata Mangunsari di Gunungpati,

7). Agrowisata Kebun Durian Temu Kencono / Simbar Gunungpati;

8). Bumi Perkemahan Karanggeneng;

c). Wisata Buatan:

1). BSB Sport Club;

2). Rumah Makan dan pemacingan Barokah Mijen;

3). Waduk Jatibarang;

4). Rumah Makan/Pemancingan Dewandaru, dan Rumah Makan /Pemancingan Ngrembel Asri;

5). Wisata Pendidikan Unnes;

6). Rumah Makan dan Pemancingan Kebun Mulyo;

7). Wisata religi Firdaus Fatimah Zahra; Tiga Kawasan Pengembangan Pariwisata Kota (KPPK, yaitu :

1. KPPK Banyumanik dan sekitarnya

Yang dimaksud "KPPK Banyumanik dan sekitarnya" meliputi wilayah Gombel,
Tinjomoyo, Banyumanik, Srondol, Watu Gong dan sekitarnya, Kawasan tersebut memiliki berbagai jenis DTW, yaitu:

a). Wisata Budaya:

1). Vihara Budhagaya dan Pagoda Avalokiteswara Watu Gong:

2). Museum MURI dan Pabrik Jamu Jago Srondol

b). Wisata Alam:

1). Hutan Wisata Tinjomoyo;

2). Lembah Ondorante.

c). Wisata Buatan:

1). Wisata Belanja UKM Center Jawa Tengah;

2). Wisata Belanja Ada Swalayan Setiabudi;

3). Wisata Pendidikan Kampus Undip Semarang;

4). Rumah Makan Alam Indah Gombel dan Taman Tabanas Gombel;

2. KPPK Pedurungan dan sekitarnya

Yang dimaksud "KPPK Pedurungan dan sekitarnya" meliputi wilayah Pedurungan dan sekitarnya. Kawasan tersebut memiliki berbagai jenis DTW, yaitu:

a). Wisata Budaya:

1). Kampung Wisata Batik Meteseh

b). Wisata Alam: -

c). Wisata Buatan:

1). Water Park Kampung Semawis;

2). Kolam Renang Gardenia;

3). Wisata Belanja Ada Swalayan Fatmawati Pedurungan;

4). Kolam Renang Manunggal Jati, Kolam Renang Perumahan Taman 
Majapahit dan Rencana Simpang Lima II Penggaron;

5). Pasar Klithikan Penggaron, dan Giant Hypermarket Penggaron;

6). Rencana Semarang Expo Center Pedurungan;

7). Wisata Belanja Ada Swalayan Majapahit;

3. KPPK Genuk dan sekitarnya

Yang dimaksud "KPPK Genuk dan sekitarnya" meliputi wilayah Genuk dan sekitarnya. Kawasan tersebut memiliki berbagai jenis DTW, yaitu:

a). Wisata Budaya:

1). Makam Kyai Kanjeng R Adipati Surohadimenggolo

(Pangeran

Terboyo) Kaligawe, dan Makam Syekh Jamaludin Jumadil Kubro;

2). Museum dan Pabrik Jamu Nyonya Meneer Kaligawe;

3). Makam Kyai Nur Alim Sembung Harjo.

b). Wisata Alam:

1). Konservasi Mangrove Trimulyo;

2). Konservasi Mangrove Terboyo Kulon;

3). Kawasan Wisata Bahari Terboyo.

c). Wisata Buatan: Wisata Kampoeng Semarang

Strategi lunak untuk pembangunan berkelanjutan, dalam hal perencanaan dan manajemen, diterapkan di lingkungan yang dimodifikasi seperti pusat-pusat kota di mana tidak adanya lingkungan alam yang utuh membuat perlindungan lingkungan merupakan faktor yang tidak relevan mengenai kegiatan pariwisata yang sangat maju tidak tentu menimbulkan stres di lingkungan sosial dan alam. Hal yang sama berlaku untuk massa yang terdegradasi atau daerah pedesaan yang dimodifikasi, di mana pengembangan kegiatan wisata dapat menyebabkan peningkatan yang signifikan status quo dalam hal perlindungan lingkungan.

Pengembangan pariwisata berkelanjutan pada negara berkembang seperti di Ethiopia cenderung pada pengoptimalan kondisi alam dan kebudayaan lokal. Daya tarik / sumber daya pariwisata adalah komponen dasar dari industri pariwisata. Karena itu, tidak ada pariwisata tanpa daya tarik / sumber daya pariwisata. Studi kepariwisataan mampu mengidentifikasi dan mendokumentasikan sumber daya wisata potensial kota Jimma dan sekitarnya sama sekali. Seperti penelitian ini menunjukkan bahwa semua jenis sumber daya pariwisata ada di daerah studi. Sejauh menyangkut masalah konservasi, semua sumber daya wisata alam yang potensial dari wilayah studi tidak ditempatkan di bawah perlindungan hukum yang dikenal sebagai 'Kawasan Lindung'. Kurangnya aturan hukum ini menciptakan masalah serius dalam perlindungan dan pelestarian wisata alam. sumber daya di wilayah studi. Studi ini menunjukkan bahwa potensi sumber daya wisata kota Jimma dan daerah sekitarnya telah terpapar pada kerusakan manusia dan alam. Selain itu, tidak adanya basis data sumber daya pariwisata, kurangnya koordinasi antara pemegang saham yang berbeda, tidak adanya inventaris sumber daya pariwisata tingkat nasional dan kurangnya integrasi warisan sejarah dan budaya ke dalam pembangunan adalah beberapa faktor dasar yang mengakibatkan perusakan sumber daya wisata potensial di kota Jimma dan lokalitasnya.

\section{SIMPULAN}

Dengan sumberdaya alam dan budaya yang melimpah serta potensi pasar 
domestik dan internasional yang signifikan, Indonesia menghadapi tantangan tentang bagaimana menggunakan semua aset ini agar lebih bermanfaat bagi negara dan rakyatnya. Pembangunan berkelanjutan telah ditetapkan dalam kerangka hukum, namun implementasi praktisnya belum konsisten dilakukan. Sementara dukungan politis yang kuat untuk pariwisata berkelanjutan dan peluang pertumbuhan pasartetap berlanjut, orientasi sektor publik dan swasta terhadap manfaat ekonomi jangka pendek dalam pembangunan pariwisata merupakan ancaman besar. Di samping itu, sumberdaya manusia dalam pariwisata merupakan isu strategis yang akan menentukan kualitas pencapaian sasaran pembangunan nasional dan juga dalam meningkatkan daya saing global Indonesia. Dengan demikian perencanaan pengembangan pariwisata berkelanjutan perlu menitikberatkan pada pelestarian ekosistem dan lingkungan, serta dukungan dari semua pihak terkait. Sehingga tujuan pariwisata yang dapat menunjang pendapatan daerah maupun pusat tanpa mengesampingkan lingkungan hidup. Pengembangan kepariwisataan berkelanjutan perlu memperhatikan prioritas pembangunan. Dimana destinasi wisata alam dikembangkan tanpa perlu merubah ekosistem yang sedang berlangsung.

\section{DAFTAR PUSTAKA}

Aman, A . (2019). Identification and Documentation of Potential Tourism Resources: It's Management Practice in Focus in Jimma Town and its Vicinity, Southwestern Ethiopia. J Tourism Hospit 8:418

Arida, I.N.S. (2012). Buku Ajar : Pariwisata Berkelanjutan. Sustain-press

Katerina Angelevska-Najdeska and Gabriela Rakicevik. 2012. Planning of Sustainable Tourism Development. Procedia - Social and Behavioral Sciences 44 (2012) $210-220$
Miles, M.B, Huberman, A.M, dan Saldana, J. (2014). Qualitative Data Analysis, A Methods Sourcebook Edition 3. USA: Sage Publications.

Moeloeng, L.J. (2012). Metodologi Penelitian Kualitatif. Bandung: PT. Remaja Rosda Karya

Peraturan Walikota Semarang Nomor 2 Tahun 2012 tentang Badan Promosi Pariwisata Kota Semarang

Sugiyono. (2015). Metode Penelitian Kuantitatif Kualitatif dan R\&D. Bandung: Alfabeta

Yoeti. (2001) Pengantar Ilmu Pariwisata, Penerbit Angkasa, Bandung,

Wahab. (1992). Pemasaran Pariwisata, PT. Pradnya Paramita

Simamora, R.K., dan Rudi S.S., (2016). Peran Pemerintah Daerah dalam Pengembangan Pariwisata Alam dan Budaya di Kabupaten Tapanuli Utara, JPPUMA: Jurnal Ilmu Pemerintahan dan Sosial Politik UMA (Journal of Governance and Political UMA), 4 (1): 79-96.

Lubis, F.R.A., Suharyanto, A., Effendy, R., Meidasari, V.E., Shahnaz, L. (2020). Role of Facebook Advertising in Promoting Tourism in Asia. International Journal of Psychosocial Rehabilitation

Suharyanto, A. Febryani, A. Wiflihani \& Batubara, B.M. (2019). Village Government Policy on Tourism Management in Situngkir Village Research Article in Proceedings of the 2nd International Conference on Social Sciences and Interdisciplinary Studies (formerly ICCSSIS), ICCSIS 2019, 24-25 October 2019, Medan, North Sumatera, Indonesia.

A.Hidayah, N., Hutagalung, S., \& Hermawan, D. (2019). Analisis Peran Stakeholder Dalam Pengembangan Objek Pariwisata Alam Dan Sejarah Di Kelurahan Pajaresuk Kabupaten Pringsewu. Publikauma : Jurnal Administrasi Publik Universitas Medan Area, 7(1), 55-71. doi:https://doi.org/10.31289/publika.v7i1.2 179

Wal hidayat, T., \& Nasution, I. (2019). Persepsi Publik Tentang Destinasi Pariwisata Danau Toba Sebagai Global Geopark Kaldera UNESCO. Publikauma : Jurnal Administrasi Publik Universitas Medan Area, 7(2), 88-102. doi:https://doi.org/10.31289/publika.v7i2.2 943.

Dwityas, N.A., (2016), Komunikasi dan Pariwisata: Peran User Generated Content bagi Traveler dalam Media Sosial, Jurnal Simbolika: Research and Learning in Comunication Study, 2 (1): 124-133 